\title{
The Effect of Leader's Motivational Language on the Turnover Intention of SME Work-Learning Dual Workers
}

\author{
*Hyuksang Kwon , Ph.D. Student, Department of Smart Convergence Consulting, Hansung University, \\ KS013, Korea, howellkwon@gmail.com \\ Yen-yoo You, Professor, Department of Smart Convergence Consulting, Hansung University, KS013, \\ Korea, threey0818@hansung.ac.kr \\ * Corresponding author
}

\begin{abstract}
This research examines the influence of the motivational language of leaders in com panies participating in the Korean work-learning dual system on the turnover intention of wo rk-learning dual workers. The subject of this research was a questionnaire survey targeting w ork-learning dual workers of SMEs participating in the work-learning dual system. The questio nnaire consisted of 10 questions to identify demographic characteristics and 22 questions to verify the causal relationship between variables. The Likert 5-point scale was used to measur $\mathrm{e}$ the factors for the measurement items. The analysis method used the SPSS 22.0 package $\mathrm{f}$ or statistical processing of the collected 223 data. Among the leader's motivational language i $\mathrm{n}$ the company, meaning-making language has the greatest effect on the turnover intention of work-learning dual workers,followed by empathetic language. It was found that the directiongiving language among the leader's motivational language did not affect the turnover intention of work-learning dual workers. Therefore, in order to operate the work-learning dual system more effectively in the mid to long term, it was found that meaning-making language and e mpathetic language among the leader's motivational language can reduce the dropout rate of work-learning dual workers. In order to operate an effective work-learning dual system, studi es on various variables that can affect the reduction of turnover intention of work-learning $d$ ual workers should be conducted.
\end{abstract}

Keywords: Leader's Motivational Language, Meaning-making Language, Empathetic Language, Di rection-giving Language, Turnover Intention, Work-learning Dual System.

Received: 09.12.2020 $\quad$ Accepted: 10.01.2021 $\quad$ Published: 07.02.2021

\section{INTRODUCTION}

The Korean Ministry of Employment and Labor is operating a Korean apprenticeship system, a worklearning dual system, in order to cultivate and utilize on-the-job talents that companies need in the field. It aims to foster practical talents by hiring job seekers as workers and conducting education and training at industrial sites and training institutions. Basically, the work-learning dual system provides on-site training(OJT) and off-site training(Off-JT) in connection with the company's production site after a company hires job seekers as employees. Work-learning dual workers who have completed education and training are granted national qualifications through competency evaluation conducted by the government. The Korean work-learning dual system, which began in 2013, is a system that introduces apprenticeships that are spread around the world, such as dual systems from Germany, Switzerland, and Austria, and apprentices from Australia and the United Kingdom. The work-learning dual system is a more expensive training support project than other government-supported training projects. Some of the participants contributed to the improvement of job quality, such as being hired as regular workers, but the dropout rate is high, and countermeasures are needed. In the apprenticeship system of Germany and Switzerland, the cause of dropout was said to be related to occupation or firm. The main reason was that there was a conflict with a company field teacher or a senior at work, or there were not many jobs. In addition, it was explained for reasons of family problems, health problems, poor working environment, bad working atmosphere, etc.[1]. As the main reason for the dropout of the work-learning dual system is the conflict with the company's corporate field teachers or seniors in the workplace, the role of a leader in the workplace is most important to effectively operate the work-learning dual system. 


\section{Theory and formula}

\subsection{Concept of Leader's Motivational Language}

A leader's motivational language was defined as a word used by leaders to express emotions or communicate through language to meet human needs or achieve organizational goals. Leader's motivational language is said to be a means to reduce uncertainty about the job and organization and induce the direction of action for the development of members and careers[2]. The motivational language was divided into three categories: a meaning-making language, an empathetic language, and a direction-giving language[3].

\subsubsection{Direction-giving Language}

Direction-giving Language refers to a language that provides clear guidelines and provides directions for organizational members' job orientation, job attitudes, and organizational norms. Achievement of goals can be the best goal for an organization, and if the leader uses a language that gives guidance in a more efficient way to the members of the organization, they can be immersed in that direction and the efficiency of work is maximized accordingly[4].

\subsubsection{Empathetic Language}

Empathetic Language is a language that raises morale through interest, encouragement, and praise to members of the organization. In order to improve productivity in organizational management, praise is more necessary than reprimand. When the morale of the members of the organization declines and becomes an obstacle to improving productivity, words such as praise or encouragement from the leader are very important[4].

\subsubsection{Meaning-making Language}

Meaning-making language is a language in which members of the organization are well informed of the culture and atmosphere of the organization and give advice on how to gain recognition from the organization they belong to. The meaningful words of a leader in an organizational life can influence a person's view of life, and furthermore, they can become the main characters of the organization's growth and development, which is a common purpose[4].

\subsection{Concept of Turnover Intention}

Turnover Intention is a voluntary intention or thought that an organization member wants to leave the current organization in a specific situation, and it means an individual's psychological reaction state[5]. The turnover is that individuals who receive financial compensation from the organization voluntarily give up their role as members of the organization. Turnover intention is the predecessor to this turnover behavior, and it is said that it is the behavior intention that can predict the voluntary turnover of members[6].

\subsection{Concept of Work-learning Dual Worker}

Work-learning dual workers are those who receive education and training by participating in education and training programs under the work-learning dual system. Work-learning dual workers are actually in charge of work and are receiving education and training at the same time, so they also have the status of trainees. Work-learning dual workers are workers who have signed an employment contract with the company[7].

\section{Experimental setup}

2.1. The Model of Research

Based on the research results of previous researchers, this research attempted to examine the effect of the leader's motivational language on the turnover intention of work-learning dual worker participating in the Korean work-learning dual system. Figure 1 is a research model showing the relationship between the variables to be studied [Figure 1]. 
$\mathrm{H} 1$

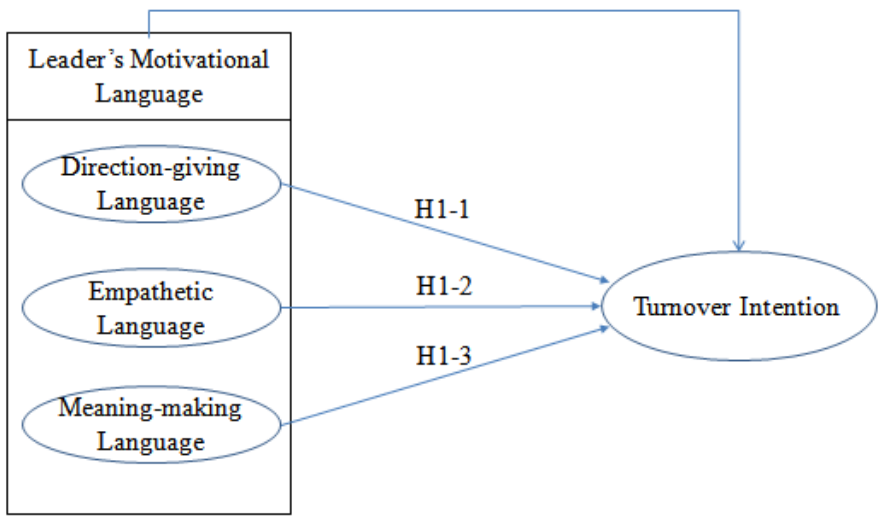

Figure 1. Research Model

\subsection{Hypothesis}

H1. Leader's motivational language will be negatively related to the turnover intention of work-learning dual workers.

H1-1. Direction-giving language will be negatively related to the turnover intention of work-learning dual workers.

H1-2. Empathetic language will be negatively related to the turnover intention of work-learning dual workers.

H1-3. Meaning-making language will be negatively related to the turnover intention of worklearning dual workers.

\subsection{Operational Definition for Measurement}

In this research, based on previous studies, the elements of the leader's motivational language were composed of three sub-factors: meaning-making language, empathetic language, and direction-giving language. Meaning-making language is a type of language allowing you to adapt well to the organizational culture and to work well in accordance with the organizational culture. Empathetic language refers to the type of language that shows interest in team members. Directiongiving language is a task-oriented language and refers to a type of language that tells you the direction and norms of a clear work attitude so that you can do your job well[8]. Turnover intention refers to an individual's psychological reaction state with the intention or thought of a member to give up being a member of the organization currently working in a specific situation and to leave for another organization $[5,10]$. The operational definitions for the variables used are summarized in [Table 1].

Table 1. Operational Definition for Measurement

\begin{tabular}{|c|c|c|c|}
\hline $\begin{array}{l}\text { Measuremen } \\
\text { t Items }\end{array}$ & Variable & Operational Definition & $\begin{array}{l}\text { Prior } \\
\text { Researc } \\
\text { h }\end{array}$ \\
\hline \multirow{3}{*}{$\begin{array}{l}\text { Leader's } \\
\text { Motivational } \\
\text { Language }\end{array}$} & $\begin{array}{l}\text { Direction- } \\
\text { giving } \\
\text { Language }\end{array}$ & $\begin{array}{l}\text { Providing guidance to give you an understanding of your work, } \\
\text { Advice on changes in the past that have affected work, Advice } \\
\text { on what to do, Providing clear guidance to solve problems, } \\
\text { Advice on future changes that may affect your work. }\end{array}$ & \multirow{3}{*}[8,9]{} \\
\hline & $\begin{array}{l}\text { Empathetic } \\
\text { Language }\end{array}$ & $\begin{array}{l}\text { Expressing encouragement for hard work, Expressing praise } \\
\text { when you did a good job, Questions about job satisfaction, } \\
\text { Organizational sponsorship for personal development, } \\
\text { Expressing interest in satisfaction with professional mission. }\end{array}$ & \\
\hline & $\begin{array}{l}\text { Meaning- } \\
\text { making } \\
\text { Language }\end{array}$ & $\begin{array}{l}\text { Storytelling about people who have worked hard at the } \\
\text { company, Advice on how to integrate with company people, } \\
\text { Storytelling about who is particularly recognized in the } \\
\text { company, Storytelling about people who left the company, }\end{array}$ & \\
\hline
\end{tabular}




\begin{tabular}{l|l|l|l}
\hline & & $\begin{array}{l}\text { Advice on how to behave in a meeting, Storytelling about } \\
\text { people who have been rewarded by the company. }\end{array}$ & \\
\hline $\begin{array}{l}\text { Turnover } \\
\text { Intention }\end{array}$ & $\begin{array}{l}\text { Thinking of leaving a job when there is a better company, The } \\
\text { Intention } \\
\text { thought of wanting to work for another company, Often } \\
\text { searching for job ads from other companies, Thinking seriously } \\
\text { about quitting the current company, Possibility not to select the } \\
\text { current company when reselecting, The idea of moving to a new } \\
\text { company. }\end{array}$ & [10] \\
\hline
\end{tabular}

\section{Result discussions}

3.1. Empirical Analysis Results

\subsubsection{Demographic Characteristics}

The demographic characteristics of the survey subjects were identified through frequency analysis As a result of analysis, it was composed of a total of 223 copies, and it was confirmed that there were no missing values. The results of frequency analysis indicating demographic characteristics of the survey subjects are summarized in [Table 2].

Table 2. Demographic Characteristics

\begin{tabular}{|c|c|c|c|c|}
\hline Classification & Contents & $\begin{array}{l}\text { Frequency } \\
\text { (Person) }\end{array}$ & $\%$ & Person \\
\hline \multirow{2}{*}{ Gender } & Male & 182 & 81.6 & \multirow{2}{*}{223} \\
\hline & Female & 41 & 18.4 & \\
\hline \multirow{4}{*}{ Age } & Under 20 & 10 & 4.5 & \multirow{4}{*}{223} \\
\hline & $20 \mathrm{~s}$ & 191 & 85.7 & \\
\hline & $30 \mathrm{~s}$ & 14 & 6.3 & \\
\hline & Over 40s & 8 & 3.6 & \\
\hline \multirow{4}{*}{ Education Level } & High school graduation & 202 & 90.6 & \multirow{4}{*}{223} \\
\hline & College graduation & 6 & 2.7 & \\
\hline & University graduation & 12 & 5.4 & \\
\hline & Graduate or above & 3 & 1.3 & \\
\hline \multirow{2}{*}{ Marital Status } & Single & 196 & 87.9 & \multirow{2}{*}{223} \\
\hline & Married & 27 & 12.1 & \\
\hline \multirow{4}{*}{ Working Years } & Under 1 year & 10 & 4.5 & \multirow{4}{*}{223} \\
\hline & 1 year or more less than 2 years & 164 & 73.5 & \\
\hline & 2 years or more less than 4 years & 31 & 13.9 & \\
\hline & More than 4 years & 18 & 8.1 & \\
\hline \multirow{5}{*}{ Sectors } & \begin{tabular}{|l|} 
Manufacturing \\
\end{tabular} & 164 & 73.5 & \multirow{5}{*}{223} \\
\hline & Wholesale and retail & 18 & 8.1 & \\
\hline & Construction & 24 & 10.8 & \\
\hline & Service & 7 & 3.1 & \\
\hline & Others & 10 & 4.5 & \\
\hline \multirow{5}{*}{ Job Area } & $\begin{array}{l}\text { Planning, management, general affairs, } \\
\text { personnel }\end{array}$ & 17 & 7.6 & \multirow{5}{*}{223} \\
\hline & Sales, marketing & 9 & 4.0 & \\
\hline & R\&D, design & 51 & 22.9 & \\
\hline & Production, manufacturing & 135 & 60.5 & \\
\hline & Others & 11 & 4.9 & \\
\hline
\end{tabular}

\subsubsection{Descriptive Statistics}

The collected data was analyzed by surveying work-learning dual workers working in SMEs participating in the work-learning dual system, a Korean apprenticeship system. As a result of checking the standard deviation, kurtosis, and skewness of the quantitative scale data, it was found that the measured variables follow a normal distribution. The skewness value was less than the reference absolute value, and the kurtosis value was also less than the reference absolute value, which did not violate normality. 


\subsubsection{Reliability and Validity Analysis}

The validity of the measurement tool was verified through exploratory factor analysis. KMO and Bartlett's test of sphericity were selected. Principal component analysis was used to extract constituent factors, and varimax was adopted to simplify factor loading. As a result of factor analysis, the KMO value was 0.896, which was quite good with a general standard of 0.7 or more. As the result of Bartlett's test of sphericity, it is suitable for factor analysis because the p-value was found to be .000 less than .05 . Reliability analysis was conducted on the measurement items for which validity was secured. Cronbach's $\alpha$ coefficients of all measurement variables are over 0.6 , which is the general standard, showing high reliability. The results of reliability analysis and validity analysis are summarized in [Table 3].

Table 3. Results of Reliability and Validity Analysis

\begin{tabular}{|c|c|c|c|c|c|c|}
\hline \multirow{2}{*}{$\begin{array}{l}\text { Measurement } \\
\text { Items }\end{array}$} & \multicolumn{4}{|c|}{ Exploratory Factor Analysis } & \multirow[b]{2}{*}{ Communality } & \multirow{2}{*}{\begin{tabular}{|l|}
$\begin{array}{l}\text { Reliability } \\
\text { Analysis }\end{array}$ \\
Cronbach's \\
$\alpha$ \\
Coefficients \\
\end{tabular}} \\
\hline & $\begin{array}{l}\text { Meaning- } \\
\text { making } \\
\text { Language } \\
\end{array}$ & $\begin{array}{l}\text { Turnover } \\
\text { Intention }\end{array}$ & $\begin{array}{l}\text { Empathetic } \\
\text { Language }\end{array}$ & $\begin{array}{l}\text { Direction- } \\
\text { giving } \\
\text { Language } \\
\end{array}$ & & \\
\hline Meaning lang. 1 & .819 & -.288 & .187 & .160 & .813 & \multirow{6}{*}{.904} \\
\hline Meaning lang. 2 & .817 & -.221 & .225 & .038 & \begin{tabular}{|l|}
.768 \\
\end{tabular} & \\
\hline Meaning lang. 4 & .718 & -.226 & .193 & .152 & .626 & \\
\hline Meaning lang. 3 & .694 & -.263 & .106 & .247 & .623 & \\
\hline Meaning lang. 5 & .679 & -.364 & .144 & .321 & .717 & \\
\hline Meaning lang. 6 & .648 & -.372 & .162 & .145 & .606 & \\
\hline $\begin{array}{l}\text { Turnover Intent } \\
5\end{array}$ & -.327 & .785 & -.151 & -.114 & .759 & \multirow{6}{*}{.895} \\
\hline $\begin{array}{l}\text { Turnover Intent } \\
1\end{array}$ & -.346 & .756 & -.001 & -.162 & .718 & \\
\hline $\begin{array}{l}\text { Turnover Intent } \\
6\end{array}$ & -.174 & .754 & -.234 & -.189 & .689 & \\
\hline $\begin{array}{l}\text { Turnover Intent } \\
3\end{array}$ & -.277 & .751 & -.071 & -.171 & .675 & \\
\hline $\begin{array}{l}\text { Turnover Intent } \\
2\end{array}$ & -.271 & .691 & -.280 & -.140 & .649 & \\
\hline $\begin{array}{l}\text { Turnover Intent } \\
4\end{array}$ & -.254 & .592 & -.372 & -.140 & .573 & \\
\hline $\begin{array}{l}\text { Empathetic lang. } \\
1\end{array}$ & .102 & -.126 & .832 & .279 & .797 & \multirow{5}{*}{.911} \\
\hline $\begin{array}{l}\text { Empathetic lang. } \\
4\end{array}$ & .212 & -.204 & .818 & .223 & .804 & \\
\hline $\begin{array}{l}\text { Empathetic lang. } \\
5\end{array}$ & .166 & -.115 & .807 & .227 & .744 & \\
\hline $\begin{array}{l}\text { Empathetic lang. } \\
3\end{array}$ & .134 & -.118 & .757 & .247 & .666 & \\
\hline $\begin{array}{l}\text { Empathetic lang. } \\
2\end{array}$ & .284 & -.290 & .711 & .172 & .700 & \\
\hline Direction lang. 1 & .126 & -.051 & .307 & .820 & .785 & \multirow{5}{*}{.906} \\
\hline Direction lang. 3 & .177 & -.138 & .266 & .793 & .751 & \\
\hline Direction lang. 2 & .078 & -.122 & .277 & .791 & .723 & \\
\hline Direction lang. 4 & .242 & -.249 & .127 & .774 & .736 & \\
\hline Direction lang. 5 & .217 & -.272 & .183 & .750 & .717 & \\
\hline Eigen-value & 4.028 & 4.011 & 3.864 & 3.737 & & \\
\hline$\%$ of Variance & 18.308 & 18.231 & 17.565 & 16.984 & & \\
\hline Cumulative \% & 18.308 & 36.539 & 54.104 & 71.088 & & \\
\hline \multicolumn{6}{|c|}{ Kaiser-Meyer-Olkin(KMO) Measure } & .896 \\
\hline $\begin{array}{l}\text { Bartlett's Test } \\
\text { of Sphericity }\end{array}$ & $\chi^{2}$ & 3775.887 & $\mathrm{df}$ & 231 & $\mathrm{p}$-value & 0.000 \\
\hline
\end{tabular}




\subsubsection{Pearson's Correlation Analysis}

After going through the process of purifying the parameters of the measurement tool through exploratory factor analysis and reliability analysis, the variables were calculated. The correlation between the variables was confirmed as a result of correlation analysis. In the correlation analysis result, it was found that there was a significant relationship among all variables under the .01 significance level. The correlation coefficient between the directiongiving language and the empathetic language is $.574^{* *}$, indicating that there is a rather high correlation. The correlation coefficient between direction-giving language and meaningmaking language showed a value of $.489^{* *}$, and the correlation coefficient between directiongiving language and turnover intention was $-.473^{* *}$. The correlation coefficient between empathetic language and turnover intention was $-.502^{* *}$, and the correlation coefficient between empathetic language and meaning-making language was $.495^{* *}$. The correlation coefficient between meaning-making language and turnover intention was -.699** The correlation analysis results are summarized in [Table 4].

Table 4. Results of Correlation Analysis

\begin{tabular}{l|l|l|l|l|l|l|l}
\hline Constructs & $\mathbf{N}$ & Mean & $\begin{array}{l}\text { Standar } \\
\mathbf{d} \\
\text { Deviatio } \\
\mathbf{n}\end{array}$ & $\begin{array}{l}\text { Direction- } \\
\text { giving } \\
\text { Language }\end{array}$ & $\begin{array}{l}\text { Empathetic } \\
\text { Language }\end{array}$ & $\begin{array}{l}\text { Meaning- } \\
\text { making } \\
\text { Language }\end{array}$ & $\begin{array}{l}\text { Turnover } \\
\text { Intention }\end{array}$ \\
\hline $\begin{array}{l}\text { Direction- } \\
\text { giving } \\
\text { Language }\end{array}$ & 223 & 3.7722 & .75393 & 1 & $.574^{* *}$ & $.489^{* *}$ & $-.473^{* *}$ \\
\hline $\begin{array}{l}\text { Empathetic } \\
\text { Language }\end{array}$ & 223 & 3.7489 & .71135 & $\mathbf{. 5 7 4}$ & 1 & $.495^{* *}$ & $-.502^{* *}$ \\
\hline $\begin{array}{l}\text { Meaning- } \\
\text { making } \\
\text { Language }\end{array}$ & 223 & 4.0710 & .58473 & $\mathbf{. 4 8 9 ^ { * * }}$ & $\mathbf{. 4 9 5}^{* *}$ & 1 & $-.699^{* *}$ \\
\hline $\begin{array}{l}\text { Turnover } \\
\text { Intention }\end{array}$ & 223 & 1.9372 & .57998 & $\mathbf{- . 4 7 3 ^ { * * }}$ & $\mathbf{- . 5 0 2}^{* *}$ & $\mathbf{- . 6 9 9 ^ { * * }}$ & 1 \\
\hline
\end{tabular}

${ }^{* *}$. The correlation is significant at the .01 level (both sides).

\subsection{Hypothesis Test Result}

Multiple regression analysis was conducted to test the hypotheses between the meaningmaking language, empathetic language, and direction-giving language, which are the sub-factors of the leader's motivational language, and the turnover intention of work-learning dual workers participating in work-learning dual system. The results of the hypothesis test are summarized in [Table 5].

Table 5. Results of Multiple Regression Analysis

\begin{tabular}{|c|c|c|c|c|c|c|}
\hline Model & B & $\beta$ & $t$ & p-value & VIF & Result \\
\hline (Constant) & 5.025 & & 25.165 & .000 & & \\
\hline $\begin{array}{l}\text { Direction-giving } \\
\text { Language }\end{array}$ & -.078 & -.101 & -1.709 & .089 & 1.626 & Reject \\
\hline $\begin{array}{l}\text { Empathetic } \\
\text { Language }\end{array}$ & -.133 & -.163 & -2.734 & .007 & 1.639 & Accept \\
\hline $\begin{array}{l}\text { Meaning-making } \\
\text { Language }\end{array}$ & -.564 & -.569 & -10.188 & .000 & 1.444 & Accept \\
\hline
\end{tabular}

$\mathrm{R}^{2}=.527$, Adjusted $\mathrm{R}^{2}=.521, \mathrm{~F}=81.386(\mathrm{p}=<.001)$, Durbin-Watson=1.979

Dependent Variable : Turnover Intention

As for the effect of the direction-giving language on the turnover intention, the $t$ value was 1.709 ( $p=.089$ ), and the hypothesis H1-1 was rejected. As for the effect of empathetic language on turnover intention, the $t$ value was $-2.734(\mathrm{p}=.007)$, and the hypothesis H1-2 was adopted. As for the effect of meaning-making language on the turnover intention, the $t$ value was $-10.188(p=.000)$, and 
the hypothesis H1-3 was adopted. In other words, it was found that empathetic language and meaning-making language had a negative(-) effect on turnover intention under the statistical significance level. The results of the hypothesis test on the motivational language of the leader and the turnover intention of work-learning dual workers participating in work-learning dual system are summarized in [Figure 2].

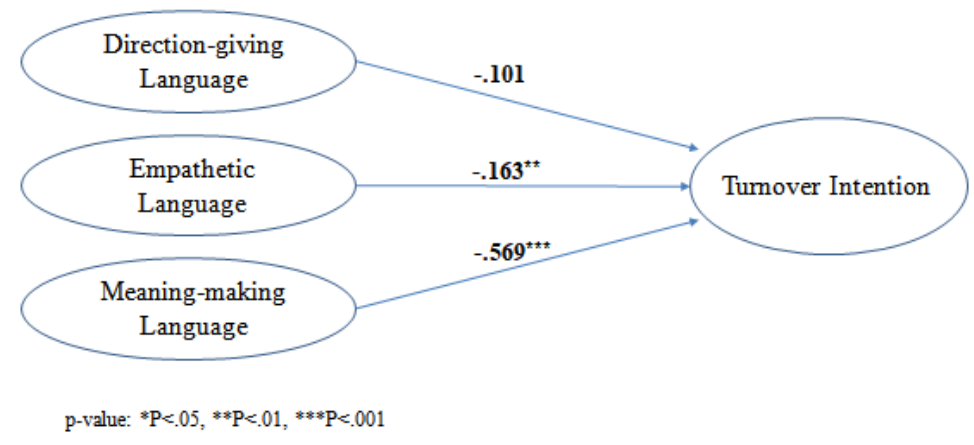

Figure 2. Test Result of Leader's Motivational Language on the Turnover Intention

\section{Conclusions}

In order to improve the competitiveness of SMEs, the Korean Ministry of Employment and Labor is operating the work-learning dual system, which is a training support project at a high cost to help them cultivate and utilize practical talents necessary in the field of SMEs. The work-learning dual system has also contributed to the positive aspects of nurturing practical talents required by companies, but the dropout rate of learning workers is high, which requires countermeasures. This research investigated the effect of the motivational language of a company field teacher or a workplace senior leader on the turnover intention of work-learning dual workers of SMEs participating in the work-learning dual system. In summarizing the research results, meaning-making language and empathetic language among leader's motivational language had a negative(-) effect on turnover intentions of work-learning dual workers. Among them, meaning-making language was found to have the greatest influence, followed by empathetic language. It was found that the direction-giving language among the leader's motivational languages did not affect the turnover intention of work-learning dual workers. It was confirmed that meaning-making language and empathetic language are important among the motivational languages of company field teachers or senior leaders in order to reduce turnover, which is a cause of dropout during work-learning dual system training. Since the purpose of the work-learning dual system is to develop the job skills of work-learning dual workers through education and training and to increase the productivity of the company, the work-learning dual system can be operated more effectively in the mid to long term by reducing the dropout rate of work-learning dual workers. Research on a variety of new variables that can affect the reduction of turnover intention, which is one of the main reasons for the dropout rate of worklearning dual workers under the work-learning dual system, should be conducted.

\section{Acknowledgements}

This research was financially supported by Hansung University.

\section{References}

[1] Stalder, B. E., E. Schmid, \& E. Schmid, (2006) "Lehrvertragsauflösungen, ihre Ursachen und Konsequenzen: Ergebnisse aus dem Projekt LEVA," Erziehungsdirektion des Kantons Bern, Bildungsplanung und Evaluation.

[2] Rowley Mayfield, J., M. R. Mayfield, \& J. Kopf, (1998) "The effects of leader motivating language on subordinate performance and satisfaction," Human Resource Management: Published in Cooperation with the School of Business Administration, The University of Michigan and in alliance with the Society of Human Resources Management, 37(3-4), 235-248.

[3] Sullivan, J. J., (1988) "Three roles of language in motivation theory," Academy of Management Review, 13(1), 104-115.

[4] Kim, E. J., \& T. J. Cho, (2013) “The Effects of Leader's Motivational Language on Self-Esteem, SelfEfficacy and Organizational Commitment," The Korean Journal of Human Resource Development Quarterly, 15(4), 1-25. 
[5] Moon, Y. J., (2011) "Effects of Individual Motivation on Turnover Intention among Social WorkersWith a focus on the mediation effects of multiple commitments," Korean Journal of Social Welfare Studies, 42(2), 493-523.

[6] Mobley, W. H., (1977) "Intermediate linkages in the relationship between job satisfaction and employee turnover," Journal of applied psychology, 62(2), 237.

[7] Kweon, T. S., (2018) "The Effects of Apprenticeship Workers' Perceived Organizational Support, Job Satisfaction, Career Commitment, Affective Involvement on the Turnover Intention," Doctoral dissertation, Korea University of Technology Education, Cheonan, Korea.

[8] Yang, J. W., (2011) "A Study on the Relationship between Team Leader's Motivational Language and Subordinate's Job Performance and Satisfaction," Master's thesis, Ewha Womans University, Seoul, Korea.

[9] Mayfield, J., \& M. Mayfield, (2009) "The role of leader motivating language in employee absenteeism," The Journal of Business Communication (1973), 46(4), 455-479.

[10] Kang, I. J., (2015) "The relationships among Turnover Intention, Career related Learning, Career Motivation, Perceived Organizational Support, Organizational Commitment, Career Commitment and Employability of Office Workers in Large Corporations," Doctoral dissertation, Seoul National University, Seoul, Korea. 